NBER WORKING PAPER SERIES

\title{
SUBSIDIES TO EMPLOYEE HEALTH INSURANCE PREMIUMS AND THE HEALTH INSURANCE MARKET
}

\author{
Jonathan Gruber \\ Ebonya Washington \\ Working Paper 9567 \\ http://www.nber.org/papers/w9567 \\ NATIONAL BUREAU OF ECONOMIC RESEARCH \\ 1050 Massachusetts Avenue \\ Cambridge, MA 02138 \\ March 2003
}

We are very grateful to Bill Anderson of the Office of Personnel Management, Steve Barber of the Postal Service, Rose Chu and James Mays of Actuarial Research Corporation, and Walt Francis for assistance in providing the data and helpful conversations. We are also grateful to Amy Taylor for alerting us to this change in FEHBP policy, to Dan Feenberg for assistance with the TAXSIM model, and to Avi Ebenstein and David Seif for research assistance. Gruber gratefully acknowledges funding from the Economic Research Initiative on the Uninsured at the University of Michigan and from the Commonwealth Fund. The views expressed herein are those of the authors and not necessarily those of the National Bureau of Economic Research.

(C2003 by Jonathan Gruber and Ebonya Washington. All rights reserved. Short sections of text not to exceed two paragraphs, may be quoted without explicit permission provided that full credit including Cnotice, is given to the source. 
Subsidies to Employee Health Insurance Premiums and the Health Insurance Market Jonathan Gruber and Ebonya Washington

NBER Working Paper No. 9567

March 2003

JEL No. I1, H2

\section{ABSTRACT}

One approach to covering the uninsured that is frequently advocated by policy makers is subsidizing the employee portion of employer-provided health insurance premiums. But, since the vast majority of those offered employer-provided health insurance already take it up, such an approach is only appealing if there is a very high takeup elasticity among those who are offered and uninsured. Moreover, if plan choice decisions are price elastic, then such subsidies can at the same time increase health care costs by inducing selection of more expensive plans. We study an excellent example of such subsidies: the introduction of pre-tax premiums for postal employees in 1994, and then for the remaining federal employees in 2000. We do so using a census of personnel records for all federal employees from 1991 through 2002. We find that there is a very small elasticity of insurance takeup with respect to its after-tax price, and a modest elasticity of plan choice. Our results suggest that the federal government did little to improve insurance coverage, but much to increase health care expenditures, through this policy change.

Jonathan Gruber

Department of Economics

MIT, E52-355

50 Memorial Drive

Cambridge, MA 02142-1347

and NBER

gruberj@mit.edu
Ebonya Washington

Department of Economics

MIT

50 Memorial Drive

Cambridge, MA 02142-1347 
The number of uninsured persons in the United States has risen steadily over the past two decades. Forty-one million Americans, or 14.6 percent of the nonelderly population, is without health insurance coverage (Center on Budget and Policy Priorities, 2002). This is despite significant expansions in the public insurance safety net over the past 15 years, particularly for children. Thus, many have advocated an alternative approach to increasing insurance coverage: subsidizing individuals to take advantage of their existing employer-provided insurance options.

The appeal of this approach is motivated by two facts. First, roughly one-quarter of the uninsured are individuals who are offered health insurance through their job or the job of a family member, but do not take it up. These are individuals who have access to the employerprovided insurance system, and for whom employers are already paying a sizeable share of their insurance costs. Thus, it seems that these are the "low hanging fruit" of the uninsured population, the cheapest group to bring into the ranks of the insured. Second, the decline in insurance coverage over the past two decades has been almost exclusively through reduced takeup of insurance among those offered, not reduced offering. So premium subsidies are motivated as a means of offsetting this pernicious time trend.

But such subsidies will only be effective if the decision to take up employer-provided insurance conditional on offering is very price elastic. A small number of studies suggests that this is not the case, finding that takeup decisions are not very sensitive to employee premiums. But this existing literature generally suffers from the problem that employee premiums are a choice variable of the firm, and they might therefore respond to employee tastes for insurance, potentially biasing any estimated takeup elasticities. What is required to estimate elasticities is exogenous variation in the price of insurance that is independent of employee tastes.

In this paper we study such an exogenous price change, through tax subsidization of the 
employee share of premiums for federal workers in the Federal Employee Health Benefit Program (FEHBP). Roughly one-half of all employees in the U.S. pay their insurance premiums on a pre-tax basis (Gruber and McKnight, 2002). But, until 1994, employee premium payments were made on a post-tax basis by virtually all federal employees insured through the Federal Employee's Health Benefit Program (FEHBP). Then, in 1994, employees of the postal service, who represent roughly one-third of all federal workers, were given the right to pay their insurance premiums on a pre-tax basis. The remaining federal employees were given this right in October, 2000 (for the 2001 plan year open enrollment).

These changes provide an excellent laboratory for learning about the impact of premium subsidies on insurance takeup. The changes introduced a sizeable reduction in the after-tax price of FEHBP insurance for postal workers in 1994, and then for all remaining federal workers in 2000. Moreover, the reduction varies by income group (due to the differential tax benefits of tax-shielded premium payments) and states (due to differential state income tax rates). Thus, there is extensive variation across otherwise identical workers in the after-tax size of employee premiums.

We use this laboratory to ask two questions about the impact of premium subsidies on the market for employer provided health insurance. First, can premium subsidies effectively increase the takeup of employer-provided health insurance? Second, how do premium subsidies impact the cost of employer-provided health insurance? By subsidizing insurance costs on the margin, premium subsidies may encourage employees to choose more expensive health insurance plans. This can serve to increase total health care costs even as it increases takeup among the existing uninsured. 
We explore these issues using a unique and valuable new source of data: a complete census of personnel records for all federal employees since 1991. These personnel records include information on health insurance takeup, plan choice, and type (single or family) of plan choice. We match this plan choice and type information with publicly available data on the cost of each insurance plan offered to federal employees. In addition, the individual micro-data provide sufficient information on federal employee earnings and other characteristics to compute the impact of the tax subsidy on the individual employee.

We have two central findings. First, there is only a very small impact of premium subsidies on the decision to take up insurance, with elasticities of insurance takeup of roughly -0.02 . Second, there is a modest impact of premium subsidies on plan costs, so that subsidizing premiums in the FEHBP significantly raised program costs. Overall, we estimate that the premium subsidies introduced by FEHBP cost the government roughly $\$ 700$ million dollars, while newly insuring at most 11,000 to 22,000 new persons, for a cost per newly insured of $\$ 31,000$ to $\$ 83,000$.

Our paper proceeds as follows. Part I presents some background on the employerprovided health insurance market, and discusses the case for and against premium subsidies. Part II discusses the key institutional features of the FEHBP and the policy change we study. Part III presents our unique data set and the empirical strategy we will employ to study it. Part IV presents our results, and in Part V we compute the benefits and costs to the government from this policy change. Part VI concludes. 


\section{Part I: Background}

Employee Contributions for Health Insurance

Currently, on average, employees pay $\$ 174$ per month for family coverage, and $\$ 38$ per month for single coverage. These represent $27 \%$ and $16 \%$, respectively, of the total cost of insurance to the firm. Employee percentage shares rose dramatically from 1988 to 1993, then fell by the middle of the decade before remaining relatively stable over the past few years (Kaiser Family Foundation, 2002). In the federal employees data that we use, federal employees paid on average one-fifth of the cost of their insurance, which is fairly consistent with the private sector. On the other hand, the share of premiums paid by federal employees is almost identical for family and single plans, whereas in the private sector the share is much higher for family plans.

The rise in employee premium shares for private health insurance closely mirrors the major trend in health insurance markets of the past two decades: the decline in employerprovided health insurance coverage. The share of workers covered by employer-provided insurance fell from 80\% in 1982 to $72 \%$ in 1998 (Gruber and McKnight, 2002). The time series pattern of decline in insurance parallels the rise in employee premium contributions, with the largest reduction in insurance occurring in the 1988-1993 period when employee premiums were rising most rapidly.

This close correspondence naturally suggests a causal role for employer premium sharing policies in driving the reduction in insurance coverage during the 1980s and 1990s. This role is further supported by recent studies which suggest that most of the decline in coverage over this period was due to a reduction in employee takeup, not a reduction in employer offering of 
insurance (Cooper and Schone, 1998; Farber and Levy, 2000).

As noted by Pauly (1986), the presence of any employee contributions suggests imperfect worker sorting across firms, because in general employer contributions for health insurance are excluded from taxation while employee contributions are not. Since the time of his article, employee contributions have also become shielded from taxation in a number of firms due to the growing use of IRS Section 125 plans. But such protection of employee contributions is far from complete, although data on the prevalence of such arrangements is sketchy. The most recent available data, from a survey of employers by the Kaiser Family Foundation, suggests that half of all workers are in firms that offer such flexible benefit plans. ${ }^{1}$

Levy (1997) highlights two possible explanations for the existence of employee contributions. The first is the "fixed subsidy" model, whereby employers with multiple insurance plans ask their employees to contribute funds towards insurance in order to incentivize employees to choose the lowest cost insurance plan. If this were the only motivation for employee contributions, employers would contribute the amount of the minimum cost plan, and employers with only one plan would never have employee contributions. In fact, as Levy (1997) points out, the second of these conditions does not hold in practice: more than half of firms with only one plan require an employee contribution. Overall, she finds that only about one-sixth of

${ }^{1}$ In principle, every firm should set up a Section 125 plan to further maximize the size of the pie by making employee contributions pre-tax as well. The reason for less than full coverage of this generous tax benefit in practice is unclear, but some of it may have to do with extensive IRS regulation of these arrangements to ensure that they are not abused. For example, the regulations state that no more than $25 \%$ of the benefits of a plan can be attributed to any "highly compensated" employee, essentially ruling out the availability of section 125 plans for very small firms. Moreover, there are strict and complicated rules that limit the flexibility of employees to switch sources of insurance coverage during the year if they are paying their health insurance contributions on a pre-tax basis. 
employee contributions are paid by workers who have the option of a cheaper plan with no contribution required.

Alternative explanations for employee contributions rely on imperfect worker sorting across firms, and Levy (1997) and Dranove, Spier, and Baker (2000) present two different models of this imperfect sorting. The key notion behind these models is that there is not perfect worker-by-worker shifting of insurance costs to wages, so that with heterogeneity in tastes premium contributions become a useful tool for separating worker types. By requiring contributions, the firm can provide insurance only to those who demand it, and can pass the savings back to employees in the form of higher wages.

Levy (1997), Dranove, Spier and Baker (2000) and Gruber and McKnight (2002) provide tests of some of the predictions of these models. The evidence generally supports the important role of the imperfect worker sorting model: firms where workers have lower demand for insurance, or better outside options for insurance coverage, have higher premium payments. In particular, Gruber and McKnight find that in firms where employees have more access to public insurance through Medicaid, premium shares are higher. Gruber and McKnight also find that firms with higher worker tax rates share less of the premiums with their workers, consistent with the tax-bias towards employer payments; this conclusion is confirmed by Cutler (2002), using state average tax rates.

\section{The Case For and Against Subsidizing Employee Premiums}

There is enormous interest in the policy arena in using subsidies to employer premiums as a tool to combat uninsurance. This interest arises from two important facts, as noted in the 
introduction: roughly one-fifth of the uninsured are offered health insurance at work; and the decline in insurance coverage has been almost exclusively through reduced takeup, not reduced offering. A number of policy analysts have suggested premium subsidies as a key part of health insurance reform (e.g. Lemieux, Kendall and Levine, 2000). Premium subsidies are already encouraged as a policy option under the State Children's Health Insurance Program (SCHIP), an extension of public insurance to children up to $200 \%$ of the poverty line that was passed in 1997 . That legislation allows states to, in place of directly expanding public insurance entitlements, "buy into" the employer-provided insurance held by those newly eligible. The motivation for this type of buy-in approach is to leverage existing employer payments to expand insurance at a lower cost. As Henneberry and Hearne (1998) write "Federal and state resources for children's health insurance could cover more children if employers make contributions toward the insurance premiums for children who are eligible for SCHIP. By combining private dollars and SCHIP funds to support employer-sponsored insurance coverage rather than offering only the publicly funded program, states may be able to cover more children".

While attractive in theory, this approach runs into an important problem in practice: while a large share of the uninsured are offered health insurance, they only amount to a very small subset of the total offered population. Calculations from the 2001 Current Population Survey show that only seven percent of those offered insurance are uninsured. ${ }^{2}$ This is simply a function of the fact that the total pool of individuals offered insurance is much larger than the pool of uninsured. Thus, overall, providing subsidies for employee takeup could be a very

\footnotetext{
${ }^{2}$ Authors' tabulations from a match of the 2001 February and March supplements to the CPS.
} 
poorly targeted policy.

Moreover, takeup of insurance among those offered is high in all easily identifiable subgroups, so that it is difficult to even effectively target employee premium subsidies. Even among those below the poverty line, fewer than $25 \%$ of those offered insurance are uninsured. Between the poverty line and twice the poverty line, only $15 \%$ of those offered insurance are uninsured; between $200 \%$ and $300 \%$ of poverty, only $7 \%$ of the offered are uninsured. So this is a hard group to target even using very tight income criteria.

Thus, the key question becomes: is takeup sufficiently price elastic among the offered uninsured to overcome this poor targeting? If takeup is very price elastic, then this can be an effective tool even given the small target population.

Several previous studies have explored the price elasticity of takeup by offered employees. The first was Chernew, Frick and McLaughlin (1997). They used data from a sample of small firms in seven cities to model employee takeup of insurance as a function of employee premiums. They find significant but modest effects, with an implied elasticity of takeup with respect to employee premiums of -0.066. Blumberg, Nichols and Banthin (2002) pursued a similar approach for a nationally representative sample of firms, and found somewhat smaller effects, with an elasticity of takeup with respect to premiums of -0.04 .

The problem with this approach, however, is that both employee takeup and employee premium contributions are choice variables of the firm, and employee premiums may be endogenous with respect to the taste for insurance in the firm. If, for example, employers cover a larger share of health insurance premiums when employees don't have tastes for insurance coverage (either because of paternalism, or to meet insurer requirements on employee takeup), 
then this could lead to a downward bias to the estimated elasticity of takeup. On the other hand, if employers cover a larger share of health insurance premiums when employees have tastes for insurance coverage (because such workers demand jobs with low employee premiums), then this could lead to an upward bias. Thus, there is an uncertain bias to these previous estimates.

Cutler (2002) takes a different approach to estimating the price elasticity of takeup by offered employees: he instruments for the employee premium share with the state tax rate, under the argument that states with higher tax rates will have smaller employee premiums. Doing so, he estimates an elasticity of takeup with respect to employee premiums of -0.12 . But this approach runs into two problems in practice. First, tax rates are also directly correlated with the attractiveness of offering health insurance; Gruber and Lettau (forthcoming) find a fairly sizeable impact of tax rates on firms' decisions to offer health insurance. ${ }^{3}$ Thus, states with higher tax rates will potentially have a very different pool of firms offering insurance than states with lower tax rates, and the elasticity is estimated on the selected sample of firms that offer insurance. For example, if those workers who are newly offered when the tax rate rises are particularly unlikely to take up, then the estimate is biased downwards; if they are particularly likely to take up, then the estimate is biased upwards. Second, the average tax rate in a state may directly reflect demand for insurance, either because of the fact that it is a function of state incomes, or because policy makers respond to insurance tastes in setting state tax rates.

Cutler (2002) also makes one very important observation that had been previously missed in the literature: it does not take a very large elasticity to explain the relationship between the

${ }^{3}$ Cutler (2002) considers this possibility, but reports that tax rates are not significantly associated with new offering in his data. However, other work (Gruber, 2002a) has found that tax rates do determine offering rates in the CPS. 
rise in contributions in the 1980s and 1990s and the decline in employer-sponsored insurance takeup over this same period. Indeed, his small estimated elasticity of -0.12 can more than explain the time series trend in employer-sponsored insurance takeup.

But the literature on subsidizing employee premiums has not generally discussed another outcome of such subsidies: selection of more generous plans by those who do takeup insurance. Indeed, there is another large literature which documents the very high price sensitivity of insurance plan takeup to employee out of pocket premiums. For example, Cutler and Reber (1999) find an elasticity of plan takeup with respect to employee premiums of -2 , and Buchmueller and Feldstein (1997) find similarly large effects; see Cutler and Zeckhauser (2001) for a theoretical and empirical review of this literature. Given these high price sensitivities, it seems likely that an important outcome of premium subsidies could be higher plan costs. This would in turn translate to higher subsidy costs if the subsidies are open ended (or even to the extent that they are more generous than ex ante insurance spending by some enrollees). Even if the amount of the subsidy is capped, the selection of higher cost plans could raise employer spending on insurance, which would erode the tax base. This would significantly raise the cost of premium subsidies per newly insured.

\section{Part II: The Federal Policy Change}

\section{The FEHBP}

Federal employees are insured through the Federal Employees Health Benefit Program (FEHBP). At open enrollment each year, employees are given the choice of a range of insurance options through the FEHBP. These options consist of a set of national fee-for-service insurance 
plans, and a set of Health Maintenance Organization (HMO) plans that vary by location.

Premium contributions of employees are determined by formula, and the formula differs

for postal and non-postal workers. For non-postal workers (about two-thirds of federal

employees) and retirees, the government pays $75 \%$ of the cost of any particular plan, up to a cap which is equal to $72 \%$ of the weighted average biweekly premium for the set of plans chosen (separately for family and self-only plans). Beyond this cap, employees are responsible for $100 \%$ of plan costs. This formula changed somewhat during our sample period. Before 1999, it was based on an average of only the 5 or 6 (depending on the year) leading plans in the FEHBP. But when the FEHBP went to a broader average, it adjusted the percentages so that there was no net impact of the policy change.

Coverage of postal employees is considerably more generous. For postal employees, the government pays $88.75 \%$ of the cost of the chosen plan up to $85 \%$ of the weighted average biweekly premium of the set of plans chosen by postal employees. Once again, this formula changed during our sample period; these changes are described in more detail below.

\section{The Policy Change}

Before 1994, the federal government, like the majority of employers in this era, did not allow federal employees to pay their premiums on a pre-tax basis. Then, in 1994, as a result of collective bargaining negotiations between the postal service and its unions, an arbitrator ruled that (a) postal workers should pay a larger share of their health insurance premiums, but (b) 
those premium payments should be pre-tax. ${ }^{4}$ These changes happened at slightly different rates for different postal unions, but the overall trend was similar: an immediate reduction in after-tax costs, but an eventual rise as the increase in employee premium shares that outweighed the tax subsidy to those premiums.

In October, 2000, the remainder of Federal employees were offered "premium conversion", or pre-tax payment of their premiums. This was offered as part of a package of improvements for civil servants in President Clinton's February, 2000 budget, including a 3.7\% pay raise and improvements in FEHBP benefits coverage (Causey, 2000; OPM, 2000). This change was put in place shortly before the open enrollment for 2001. As a result, by the time of the 2001 enrollment, all federal employees could pay their premiums on a pre-tax basis. ${ }^{5}$

These changes induced quite large reductions in the after-tax price of insurance to federal employees. For example, consider a federal employee with family income of $\$ 60,000$ and living in Washington D.C., who faces a payroll tax rate of $7.65 \%$, a federal income tax rate of $28 \%$, and a district income tax rate of $9.5 \%{ }^{6}$ Suppose that this employee chooses family insurance through the Blue Cross low option plan, at an employee cost of \$2466 per year. Then premium

${ }^{4} \mathrm{~A}$ brief history of these changes is at http://www.usps.com/history/PS-CH1.HTM. We are grateful to Alan Rouf and Trina King of the U.S. Postal Service for discussing these changes with us and providing us with the necessary information to model them.

${ }^{5}$ Some very small groups of non-postal federal employees were able to pay premiums on a pre-tax basis even before 2000: employees of the Legislative branch, Judicial branch, Federal Reserve System, Comptroller of the Currency, Federal Deposit Insurance Corporation, and the Office of Thrift Supervision. Employees of these agencies amount to between 1-1.5\% of our observations in the 1991-2002 period. We exclude these employees from all of our regression analysis.

${ }^{6}$ For this example we assume that the employee is not itemizing his taxes; for our empirical work below, we explicitly model itemization. 
conversion saves that employee $45.15 \%$ of their premium costs, or $\$ 1113$. This is a large amount which is over $13 \%$ of the full cost of the plan.

More generally, Table 1 shows the impacts of the policy change on the after-tax share of premiums paid by employees. This is measured as:

ATSHARE $=($ employee premium $/$ total premium $) *\left(1-J_{f}-J_{s}-J_{s s}-J_{m c}\right)$

where $J_{\mathrm{f}}$ is the federal marginal tax rate, $J_{\mathrm{s}}$ is the state marginal tax rate, $J_{\mathrm{ss}}$ is the marginal Social Security (FICA) payroll tax rate, and $\mathrm{J}_{\mathrm{mc}}$ is the marginal Medicare HI payroll tax rate (which is distinguished from $J_{\mathrm{ss}}$ because it is uncapped, while $J_{\mathrm{ss}}$ has a maximum taxable amount) ${ }^{7}$

Table 1 shows the mean ATSHARE, separately for postal and non-postal workers, over time. For postal workers, their ATSHARE was 0.0625 before the 1994/1995 reforms. It then dropped in 1994 and 1995, as the tax subsidy was put in place but the increased premium sharing had not yet fully phased in. However, by 1996 the ATSHARE was already above its pre-reform levels, and in steady state was about 0.072 . For non-postal workers, ATSHARE was 0.25 through the year 2000, then dropped after reform to 0.16 .

Of course, a major concern with this empirical approach is that workers are not aware of this change in the tax treatment of employee premiums. While all workers were notified of this change in tax treatment, and it is noted in the guide to employee plan choice, it is possible that employees were not paying attention or do not understand the important savings associated with this policy change. The fact that we find a sizeable response below in terms of plan choice

${ }^{7}$ Premiums are not deductible from state taxes in New Jersey, which we account for in our computation of ATSHARE. 
suggest that there was some awareness of this program on the margin, but awareness may have been much less than complete. Thus, relative to a premium subsidy where all workers are fully aware and understand its savings implications, these estimated effects may be lower bounds.

But it is not clear that full information/awareness is the relevant benchmark for assessing the efficacy of public policy in this area. All such subsidy programs, which are typically carried out through the tax code, face the problem of imperfect information and understanding. Thus, this policy change for the federal government may be a reasonable approximation to the information content in a broader federal subsidy program for employee premiums.

It is also important to note that increasing insurance coverage was not the stated goal of this government policy change. This change was motivated by a desire to increase the attractiveness of federal employment by matching the type of insurance benefits offered in the private sector (OPM, 2000). It is unclear whether this goal was met. But, even though this was not the stated goal, this government policy change provided an excellent laboratory for learning about the (incidental) impacts of employee subsidies on insurance coverage.

\section{Part III: Data and Empirical Strategy}

Data

Our data for this analysis is a census of personnel records for all federal employees for each March from 1991 through 2002. These data were requested through Freedom of Information Act request, and purchased separately from the Federal Office of Personnel Management (which administers FEHBP to all non-postal employees) and the Postal Service. There are roughly 2.7 million observations per year, one-third of which are typically postal 
workers. We restrict our sample to full-time, health insurance eligible workers ages 21 to 64 whose records show valid state, race and education data (education data are only available for non-postal workers). These criteria reduce our dataset by $18 \%$ for a final sample of nearly 27 million observations. ${ }^{8}$

These data contain information on each employee's wages and salaries (including bonuses); sex, age and race; whether they are a veteran; whether they are handicapped; state; full or part-time status; and their choice of health plan (or whether they don't choose one). We match these data to information from the OPM Office of the Actuary on the employee and government cost of each plan. ${ }^{9}$ One concern with these data is that plan pricing may respond endogenously to the tax subsidization of employee choice. ${ }^{10}$ We therefore convert premium costs to real terms by assigning each plan its constant 1993 premium costs in each year, avoiding any issue of plan pricing changes in response to premium conversion; we then inflate all cost figures to \$2002 for ease of interpretability. For plans missing the 1993 cost data, we impute this value by computing the ratio of that plan's cost to the median plan cost in that plan's census region, in the year closest to 1993 for which we have plan data; we then multiply that ratio by the 1993 median cost for the region, to impute a 1993 cost for the plan.

\footnotetext{
${ }^{8}$ One concern with this sample selection is that takeup may not be responsive for older federal workers due to the regulatory requirement of five years of FEBHP coverage to qualify for retiree insurance. In fact, however, takeup rates are only modestly higher after age 50 than before. And our results are almost identical if we restrict to the sample of workers below age 50 .

${ }^{9} \mathrm{We}$ are grateful to Rose Chu of Actuarial Research Corporation and to Walt Francis for providing these data to us.

${ }^{10} \mathrm{While}$ this is not possible in principle, since the federal FFS plan is experience rated and the local HMOs are supposed to provide the government with their best area price, it may occur in practice. Feldman, Gray and Thorpe (2002) discuss a variety of incentives for local HMOs in FEHBP to adjust their pricing to the government.
} 
Although these data have a number of advantages for our purposes, they have one important weakness: they do not have complete data for perfectly assigning tax rates. In particular, these data are missing information on earnings of other family members, other family income, marital status, and itemization status. Therefore, we augment these OPM data with data on individual workers from the Current Population Survey (CPS), and with data on family taxes from the Statistics of Income data (SOI). We then impute tax rates to the workers in our sample in five steps.

First, for each observation, we create four states of the world: married, non-itemizer; married, itemizer; single, non-itemizer; and single, itemizer. Second, we impute to each observation in each state of the world the other elements of taxable income using demographic and income information from the CPS and itemization information from the SOI. For the CPS we use data on age, sex, race, education (non-postal workers only), wages, full time/part time status, and region to impute spousal earnings (for the two cases where the worker is married) and non-earned taxable income (using separate models for those married and single). We do this imputation separately for postal and non-postal workers, using data on the corresponding groups in the CPS. ${ }^{11}$ From the SOI, which is a dataset with information on all elements of taxable income and taxes paid for a nationally representative sample of workers in each year, we use information on income and state of residence to impute the average amount itemized, conditional on itemizing.

For each observation in each state of the world, we then compute the marginal tax rate.

\footnotetext{
${ }^{11}$ In order to ensure sufficient sample size, we use a rolling average of three CPS surveys around the survey year.
} 
We do this using the NBER's TAXSIM model, which takes input on the major elements of taxable income and computes both a federal and state marginal tax rate. ${ }^{12}$ We then use the CPS and SOI data to impute the odds of being married (the CPS) and of itemizing (SOI). Finally, we compute a weighted average marginal tax rate by taking the odds of being married and itemizing as the weights to average the tax rates from these four states of the world.

We then collapse the data into cells by states (51), years (12), income deciles (10), sex (2), and postal vs. non-postal workers (2), for a total of 24,480 observations. Collapsing the data in this way makes the analysis much more manageable than working with the underlying 27 million observations. Moreover, it allows us to clearly understand, and control for, the sources of variation in ATSHARE, as described below. We then weight the regressions by the number of observations in each cell, so that we replicate the underlying distribution of the microdata.

Our key dependent variables are the mean takeup rate of family plans and self-only plans in the cell, and the average (total, government plus employee) cost of the family and self-only insurance plans chosen in the cell. Since the policy change may itself impact the mix of family and self-only policies, we analyze separately these categories.

The means of our data are shown in Table 2. The takeup rate for family insurance is much higher for postal workers than for non-postal workers, which is potentially consistent with the larger subsidization of insurance for that group, although it may also reflect other factors (such as lower levels of spousal insurance coverage). This is offset to some extent by a lower takeup rate for single postal workers than for single non-postal workers. This is a high earning

${ }^{12}$ For more information about TAXSIM, see Feenberg and Coutts (1993). A public use version of TAXSIM is available at www.nber.org/taxsim . 
sample on average, with mean real wages (in \$2002) of $\$ 45,700$; earnings are higher for the nonpostal sample. Roughly one-quarter of the sample is non-white, and one-quarter is veterans, with both proportions somewhat higher in the postal than the non-postal sample. Seven percent of the sample is handicapped.

\section{Empirical Strategy}

We use the data described above to estimate equations of the form:

$$
\mathrm{Y}_{\mathrm{cpsy}}="+\$ \text { ATSHARE }_{\mathrm{cpsy}}+* \mathrm{X}_{\mathrm{cpsy}}+0_{\mathrm{c}}+8_{\mathrm{p}}+:_{\mathrm{s}}+\mathrm{J}_{\mathrm{y}}+,
$$

where $\mathrm{c}$ indexes income*sex cells; $\mathrm{p}$ indexes postal/non-postal; $\mathrm{s}$ indexes states; and $\mathrm{y}$ indexes years

$\mathrm{Y}$ is one of our dependent variables (premiums or takeup)

ATSHARE is the after-tax share of premiums paid by the employee

$\mathrm{X}$ is a set of cell-level characteristics

$0_{c}, 8_{p},:_{s}$ and $J_{y}$ are fixed effects for income*sex, postal/non-postal, states, and years

As tax subsidies lower employee premiums, given a premium sharing rule, ATSHARE

falls. This should lead to higher takeup and a shift to more expensive plans, so that the coefficient \$ is negative. We control also for the available exogenous characteristics of workers in each cell: the average real (\$2002) earnings level in the cell; the \% in each age group aged less than 25 , age $25-29, \ldots$, age $60-64$; the percent of workers who are non-white; the percent of workers who are veteran (and the percent who have missing veterans status); and the percent of workers who are handicapped (and the percent who have missing handicap status). Finally, we include a full set of fixed effects for each dimension along which our collapsed data vary; that is, we include a full set of dummies for income-sex, postal/nonpostal, states, and years.

One advantage of collapsing our underlying microdata is that the source of variation in ATSHARE is clear: it arises from variation across income-sex groups, across postal/nonpostal 
groups, across states, and across years. Obviously each of these dimensions is correlated with tastes for insurance, so we control in the regression for every category used to collapse the data. In this specification, identification therefore comes from the variation in the after-tax premium share within these groups. That is, this approach uses the fact that the tax subsidy changes for postal vs. non-postal workers over time, and that this change is differential by states and incomesex groups. Of course, there are potential concerns that other changes that are correlated with the change in the after-tax premium share could bias these estimates. Thus, we explore below the sensitivity of our findings to controls for these alternative hypotheses.

\section{Part IV: Results}

\section{Basic Results}

Figure 1 presents some graphical evidence on the aggregate impacts of these policy changes on takeup. The first line in this figure shows the difference between the ATSHARE of postal and non-postal workers; the second line shows the difference in their family insurance takeup rates. The series are rescaled so that they can be shown clearly on the same graph; the left hand axis shows the values for the difference in takeup, and the right hand axis shows the values for the difference in ATSHARE. If there is an effect of ATSHARE on takeup, then these series should move in opposite directions: as the gap in ATSHARE gets more negative (postal workers getting a larger subsidy relative to nonpostal workers), the gap in family takeup should get more positive (postal workers seeing a relative increase in takeup).

Indeed, over this period, the series are highly negatively correlated. At the same time, however, there is not a clear case that there is any impact of the actual policy changes on takeup 
decisions. When tax subsidies were introduced for postal workers in 1994, the gap in ATSHARE became more negative (so that there were larger subsidies to postal workers), but family takeup also fell for postal workers relative to non-postal workers. The family takeup gap then continued to fall in the several years thereafter as the gap in ATSHARE became positive, which is consistent with a takeup response. But this trend continued even after the ATSHARE gap flattened in 1997.

Thus, with respect to the postal change, it appears that there was simply a gradual closing of the gap in postal and nonpostal takeup rates that was unrelated to the actual change in after-tax premium costs.

There is then an enormous reduction in the ATSHARE gap in 2001, as premium conversion for nonpostal workers makes insurance much cheaper relative to postal workers. But there is no discernable movement in either 2001 or 2002 in the gap in family takeup rates. Thus, the trends in differential takeup across these groups appear to be causally unrelated to changes in ATSHARE; but this approach is fairly low powered, and does not exploit the full variation in incentives across income and state groups to allow us to control for other time trends.

Table 3 shows our basic results from the regression specification detailed above, for family and single takeup. In fact, we find that there is a negative effect of ATSHARE on family takeup, which is right-signed, and highly statistically significant. However, the estimate is quite small, implying that, for each 10 percent of premiums that the employee bears, they are 0.68 percent less likely to take up insurance. Employees pay roughly $20 \%$ of premiums, and mean family takeup is $61.5 \%$, so this implies an elasticity of takeup with respect to employee premiums of -0.022 . This is smaller than even the lowest estimates from the previous literature, and it is 
very precisely estimated. For takeup by singles, on the other hand, we find that there is a wrongsigned coefficient, implying that for each 10 percent of premiums that the employee bears, they are 0.36 percent more likely to take up insurance. Off the smaller base of takeup by single employees, this estimate implies a wrong-signed elasticity of takeup of 0.028 .

Interpreting these findings in terms of the reduction in the uninsured is difficult, since we observe only FEHBP coverage, not overall insurance rates. In particular, the positive coefficient on the single takeup regression likely arises from individuals shifting from single to family policies as the subsidy to insurance rises. For those individuals, there is clearly no change in insurance coverage, but their family members may be gaining coverage. We return to this set of issues in our policy simulations below.

The control variables have their expected signs in Table 3. One interesting finding is that the impact of higher wages is positive on takeup of family plans, but negative on takeup of single plans, suggesting that higher incomes lead to a shift from single to family coverage; this is consistent with our ATSHARE coefficients. Demand for family coverage rises, and demand for single coverage falls, with age. Non-whites and veterans are more likely to demand family coverage and less likely to demand single coverage, and, somewhat surprisingly, demand for both types of coverage is smaller for handicapped employees; this may pick up omitted income effects.

Table 4 examines the impact of after-tax premium costs on the costs of plans chosen by employees. We look at the impacts separately for employee and government share of costs, and then combine the two to look at the impacts on total costs, for both self and family plans.

We find strong evidence that lower premium shares are associated with choosing more expensive plans. For family plans, our estimates imply that, for each 10 percent increase in their 
share of the premiums, employees choose an insurance plan that costs $\$ 46$ less. This is composed of a reduction in employee spending of $\$ 15$, and a reduction in government spending of $\$ 31$. Mean family premiums in our sample are $\$ 5898$ (in $\$ 2002$ ). So this suggests that for each $\$ 590$ increase in employee premiums, the worker chooses a plan which lowers his costs by $\$ 15$.

For single plans, we find a similar pattern of results. For each ten percent increase in their share of the premiums, employees choose a plan which costs $\$ 18$ less; this is composed of a reduction in employee costs of $\$ 7$, and a reduction in government costs of $\$ 11$. Mean single premiums in our sample are $\$ 2642$ (in $\$ 2002$ ). So this suggests that for each $\$ 264$ increase in employee premiums, the worker chooses a plan which lowers his costs by $\$ 7$.

Thus, these findings suggest a fairly modest offset to higher premium costs in terms of choosing less expensive plans: employees offset only about $2.5 \%$ of the higher costs of insurance by choosing less expensive plans. But these choices do involve additional savings for the government which are two to three times as large.

These estimates are fairly small, given the previous literature on the price elasticity of plan choice. There are three possible reasons for this finding. First, these results may be biased downward (in absolute value) by the measured takeup response: to the extent that there is impact on takeup, and to the extent that those newly taking up are taking up less expensive plans, that will offset more expensive plan choice by the existing uninsured. But our takeup results are sufficiently small that any bias would be minor. ${ }^{13}$ Second, individuals may be less responsive to

${ }^{13}$ For example, imagine that those families newly taking up take up at the $1^{\text {st }}$ percentile of plan costs in our data, $\$ 4370$, rather than the sample mean of $\$ 4737$. At our estimated family takeup elasticity, this would lead to a positive bias to our estimates of total cost impacts of $\$ 2.50$, which is roughly $5 \%$ of the estimated $\$ 46$ effect. 
variation in the tax price of plans than to variation in the observed premiums. Finally, the homogeneity of plans within the FEHBP (due to legislatively mandated homogeneous benefits packages) may lower the incentive to switch, given that the financial implications of switching are small relative to the hassle costs of switching plans (and possibly providers, etc.).

\section{Omitted Factors}

One identifying assumption of the regression framework used thus far is that the relative change in after-tax premiums across postal workers and non-postal workers over this period is independent of any other factors which might determine the demand for FEHBP coverage. But this may not in fact be true. There may be other changes in the environment which are correlated with both changes in ATSHARE and changes in takeup and plan choice. The existence of such factors is suggested by the strong time trend in relative takeup between postal and nonpostal workers shown in Figure 1, which appears to be unrelated to the policy change of this era.

There are other potential issues of this nature as well. For example, it may be that states are changing their tax rates over time in response to the insurance status of their citizens, and that could cause a spurious bias between takeup decisions and after-tax prices. Alternatively, it could be that the widening of the income distribution changes the takeup decisions of higher vs. lower income federal employees, perhaps because spouses of higher income federal employees now have better insurance options.

Similarly, our regression framework also assumes that there are no important fixed differences in different groups of workers across states. But it is possible that the postal workers in one state are quite different than in another, in a way which is reflected both in their tax rates 
and their demand for insurance. To the extent that any of these omitted factors work through observed characteristics such as age, race, or wages, they will be captured by our existing set of controls. But it is possible that they may work through unobserved channels.

Thus, we consider next an alternative specification that controls for all "second-level" interactions of income/sex, postal/nonpostal, state, and year:

$$
\begin{aligned}
\mathrm{Y}_{\mathrm{cpsy}}="+\$ \text { ATSHARE }_{\mathrm{cpsy}}+{ }^{*} \mathrm{X}_{\mathrm{cpsy}}+0_{\mathrm{c}}+8_{\mathrm{p}}+:_{\mathrm{s}}+\mathrm{J}_{\mathrm{y}}+0_{\mathrm{c}} * 8_{\mathrm{p}}+0_{\mathrm{c}} *_{\mathrm{s}}+8_{\mathrm{p}} *:_{\mathrm{s}}+0_{\mathrm{c}} * \mathrm{~J}_{\mathrm{y}} \\
+8_{\mathrm{p}} * \mathrm{~J}_{\mathrm{y}}+:_{\mathrm{s}}^{*} \mathrm{~J}_{\mathrm{y}}+
\end{aligned}
$$

In this specification, we control for all interactions between postal/nonpostal and income/sex group, between income/sex group and state, between postal/nonpostal and state, between income/sex group and year, between postal/nonpostal and year, and between state and year. We allow, for example, for distinct time trends for postal and non-postal workers, to capture the trends shown in Figure 1. We also allow there to be distinct time patterns by income/sex group, and by state. And we control for any differences between postal and nonpostal workers by income level, or any differences in these groups by state. This is a much more rigorous regression specification which controls for a host of alternative explanations for our findings.

Table 5 shows the results of estimating equation (2). Adding these controls does not much change the central message of our earlier findings, although the estimates are now less precise. The coefficient on family takeup has not changed, but the standard error has risen by a factor of four, so that the estimate is insignificant. The coefficient on single takeup is now negative, suggesting that there is not (on net) a shift from single to family coverage, but it is also highly insignificant. The effect on family premiums is slightly larger than in Table 4; our estimates now 
imply that for each $\$ 590$ increase in their share of premiums, employees choose a family plan which has a cost to them which is $\$ 19$ lower (a 3.2\% offset). The effect on single premiums is now much larger than in Table 4; the effect on government spending has not changed, but the impact on own employee spending is much larger. So we now find that, for singles, employees offset each $\$ 264$ in premiums by choosing a single plan that costs $\$ 24$ less (a 9.1\% offset).

Overall, this fairly radical change to the specification did not much change the conclusions of the earlier analysis. Takeup and total costs are very modestly related to changes in the after-tax premium cost of insurance to employees.

\section{Part V: Implications}

Our results show that there is essentially no impact of employee after-tax premiums on the decision to takeup health insurance, and a small impact on the cost of health insurance plans. In this section, we use these results to simulate the implications of these policy changes for the federal government. In doing so, we can provide some guidance as to the efficiency of premium subsidies as a tool for expanding health insurance coverage.

To undertake this simulation, we must make several assumptions. Most importantly, we must make some assumption about the extent to which increased takeup comes solely from those who would otherwise be uninsured, as opposed to partly from other sources of insurance coverage. We cannot tell these channels apart in our data. Thus, for the simulations, we make two assumptions: that all of those taking up were previously uninsured; and that half of those taking up were previously uninsured. For families, we assume that taking up means bringing four new persons into the FEHBP system; for singles, it means bringing one new person into the 
system.

When those taking up were previously insured, we assume that they are giving up insurance which parallels the typical government plan in terms of costs and premium sharing, but that premium shares were not subsidized in their previous insurance. This implies some offsetting savings in terms of the employer tax break on their previous insurance costs. In practice, as we show below, these assumptions are not very important; the general pattern of findings is quite similar in all cases.

It is also unclear how to model the differential impact on employee and government costs. In the short run, any increase in government costs is a dollar for dollar cost to the U.S. taxpayer, while an increase in employee costs only raises costs to the taxpayer to the extent that these employee costs are tax subsidized. In the long run, however, if there is shifting of insurance costs to wages in the public sector (as evidence suggests to be the case in the private sector; see Gruber (2001) for a review), then the increase in government costs will be reflected in lower wages for federal employees. This will only raises costs through reduced tax revenues on federal employee wages. So, we consider both "short" and "long" run scenarios in these estimates.

We consider the impact of the premium conversion for non-postal employees in 2000 in Table 6. The first set of columns refers to the estimates of equation (1) shown in Tables 3 and 4; the second set of columns refers to the estimates of equation (2) shown in Table 5. The first column corresponds to short run, for the case where all of the coverage increase represents a reduction in the uninsured. In this case, there are 4847 newly insured families, but 1434 fewer insured singles, for a total number of newly insured persons of 17,954 . The government spends \$46 million more on its insurance premiums, which reflects both the spending on those newly 
insured, and the increased spending on the existing insured who choose more expensive plans. The cost in terms of foregone tax revenues on employee spending from this new tax subsidy is $\$ 647$ million, which reflects a small amount of subsidy to those newly insured and a large amount of subsidy to those who already held FEHBP plans. So the total cost is $\$ 693$ million, which represents spending of over $\$ 38,000$ per person newly insured by this policy.

The remaining columns vary our two key assumptions. In column 2 , we retain the short run perspective, but assume instead that only half of those newly taking up FEHBP were previously uninsured. In this case, the costs fall slightly, since we incorporate the tax savings from those already insured leaving their privately insured plans to join the government plan. But, at the same time, the number of newly insured is less than half as large $(8,261)$ for a cost per newly insured of over $\$ 83,000 .{ }^{14}$

In the third and fourth columns, we replicate the analysis from the long run perspective, when wages have been reduced to reflect the fact that the government is paying more for health insurance, so that from both sides the only loss is through reduced taxes. This lowers the cost estimates somewhat, so that total costs are now $\$ 660-\$ 665$ million, for a cost per newly insured of between $\$ 37,000$ and $\$ 73,600$.

The second set of four columns uses the estimates from Table 5 to replicate these simulation exercises. These estimates show somewhat larger net impacts on insurance coverage, since the coefficient on family takeup did not change but the coefficient on single takeup became negative in this more general specification. But costs are also higher, due to a larger increase in

\footnotetext{
${ }^{14}$ The reduction in uninsured is less than half as large because all of those dropping single coverage are losing coverage, but only half of those moving onto family coverage are assumed to be gaining coverage.
} 
the cost of plans chosen, and the costs associated with higher takeup. Thus, on net, the results are similar, with a cost per newly insured in the range of $\$ 31,000$ and $\$ 65,000$.

\section{Part VI: Conclusions}

To many policy makers and analysts, the uninsured who currently are offered health insurance coverage provide a natural population to target with public interventions. These are individuals who can easily access the benefits of group insurance, and for whom the public sector can potentially leverage the large share of costs typically already paid by employers.

But this argument ignores two central facts. First, this population is a very small share of the total population offered health insurance, making it very costly to target interventions to them. Second, the very fact that these individuals are turning down such a highly subsidized product suggests that they may not be price sensitive in their insurance decisions. While there is a small literature investigating the price sensitivity of demand among employees offered insurance, existing studies have generally relied on variation across employers in the subsidy rates of insurance to employees, which may be a direct function of tastes for insurance.

We surmount this problem by studying an explicit change in policy to subsidize the employee premiums of federal employees, first for postal workers, and then for non-postal workers. The fact that these changes had differential effects as well by income group and state of residence causes extensive variation in the impacts of the policy change which can be exploited. We do so using a unique data set which contains personnel records for every federal employee over the 1991-2002 period.

We find, consistent with previous work, that there is very little response of insurance 
takeup to premium subsidies. Our central estimates are even lower than those of previous studies, and suggest elasticities which are in the range of -0.02 . Moreover, we find that subsidizing employee premiums causes employees to choose more expensive insurance plans, further raising the cost of such interventions. Overall, our findings suggest that the federal government spent between $\$ 31,000$ and $\$ 83,000$ per person who was newly insured by the introduction of this subsidy policy. This is much higher than simulations of the costs per newly insured from most other policies that are currently contemplated for insurance expansion (Gruber, 2002).

Thus, our findings suggest that subsidizing employee premiums is unlikely to be a costeffective avenue for increasing insurance coverage. Of course, there are a number of limitations in extrapolating these findings to a broader premium subsidy program. While federal employees were notified extensively about the availability of this tax subsidy, and while the fact that premiums changed significantly suggests that it did impact their behavior, it is possible that a national program of premium subsidies that is more effectively advertised could have a bigger impact. Similarly, a more targeted subsidy program, perhaps focused on the low income populations where a larger share of those offered insurance decline that coverage, could be more cost-effective. But, given the very high takeup rates for insurance, even in low income populations, it is unlikely that even a very targeted intervention could have a major effect on the number of uninsured. It appears that policy-makers will have to look elsewhere for effective routes to expanding insurance coverage in the U.S. 


\section{References}

Blumberg, Linda, Len Nichols, and Jessica Banthin (2001). "Worker Decisions to Purchase Health Insurance," mimeo, Urban Institute.

Buchmueller, Thomas, and Paul Feldstein (1997). "The Effect of Price on Switching Among Health Plans," Journal of Health Economics, 16, 231-247.

Causey, Mike (2000). “Clinton’s Budget Proposal Contains Some Good Things for Civil Servants," Washington Post, February 3, p. B7.

Center on Budget and Policy Priorities (2002). “The Number of Americans Without Health Insurance Rose in 2001 and Appears to Be Continuing to Rise in 2002," http://www.cbpp.org/9-30-02health.htm

Chernew, Michael, Kevin Frick, and Catherine G. McLaughlin (1997). "The Demand for Health Insurance Coverage by Low-Income Workers: Can Reduced Premiums Achieve Full Coverage?," Health Services Research, 32, 453-470.

Cooper, Phillip and Barbara Schone (1997). "More Offers, Fewer Takers for Employment-Based Health Insurance: 1987 and 1996," Health Affairs, 16, 142-149.

Cutler, David (2002). "Employee Costs and the Decline in Health Insurance Coverage," NBER Working Paper \#9036.

Cutler, David and Sarah Reber (1998). "Paying for Health Insurance: The Tradeoff Between Competition and Adverse Selection," Quarterly Journal of Economics, 113, 433-466.

Cutler, David, and Richard Zeckhauser (2001). "An Anatomy of Health Insurance," in Joseph Newhouse and Anthony Culyer, eds., Handbook of Health Economics.

Dranove, David, Kathy Spier and Laurence Baker (2000). “'Competition' Among Employers Offering Health Insurance," Journal of Health Economics, 19, 121-140.

Farber, Henry, and Helen Levy (2000). "Recent Trends in Employer-Sponsored Health Insurance: Are Bad Jobs Getting Worse?," Journal of Health Economics, 19, 93-119.

Feenberg, Daniel, and Elizabeth Coutts (1993). "An Introduction to the TAXSIM Model," Journal of Policy Analysis and Management, 12, 189-194.

Feldman, Roger, Kenneth Thorpe, and Bradley Gray (2002). "Policy Watch: The Federal Employees Health Benefits Plan,” Journal of Economic Perspectives, 16, 207-218.

Gruber, Jonathan (2002a). "The Impact of the Tax System on Health Insurance Coverage," International Journal of Health Care Finance and Economics, 1, 293-304. 
Gruber, Jonathan (2002b). "The Distributional Impacts of Alternative Health Insurance Reforms," mimeo, MIT.

Gruber, Jonathan and Robin McKnight (2002). "Why Did Employee Health Insurance Contributions Rise?,” NBER Working Paper \#8878, April 2002.

Henneberry, Joan and Jeanne Hearne (1998). "Using SCHIP Funds for Health Insurance Premium Contributions: Policy Issues and Operational Challenges". Washington, D.C.: Institute for Health Policy Solutions. Available at www.ihps.org.

Kaiser Family Foundation (2002). Kaiser/HRET 2002 Employer Health Benefits Survey. Washington, D.C.: Kaiser Family Foundation.

Lemieux, Jeff, David Kendall and S. Robert Levine (2000). "A Professive Path Toward Universal Health Coverage," Progressive Policy Institute Policy Report, December 20, 2000 .

Levy, Helen (1997). "Who Pays for Health Insurance? Employee Contributions to Health Insurance Premiums," mimeo, Princeton University.

Office of Personnel Management (2000). "President Extends Health Insurance Premium Conversion to All Executive Branch Employees," mimeo, February $7^{\text {th }}, 2000$.

Pauly, Mark (1986). "Taxation, Health Insurance and Market Failure in the Medical Economy," Journal of Economic Literature, 24, 629-675.

Scanlon, Dennis, Micheal Chernew, Catherine McLaughlin, and Gary Solon (2001), "The Impact of Health Plan Report Cards on Managed Care Enrollment," forthcoming, Journal of Health Economics 


\begin{tabular}{lcc}
\hline \multicolumn{2}{c}{ Table 1: Means of After-Tax Share by Postal/Non-Postal and Year } \\
\hline Year & Postal ATSHARE & Non-Postal ATSHARE \\
\cline { 2 - 3 } 1991 & .0625 & .25 \\
1992 & .0625 & .25 \\
1993 & .0625 & .25 \\
1994 & .0502 & .25 \\
1995 & .0558 & .25 \\
1996 & .0648 & .25 \\
1997 & .0725 & .25 \\
1998 & .0729 & .25 \\
1999 & .0715 & .25 \\
2000 & .0713 & .25 \\
2001 & .0717 & .1577 \\
2002 & .0722 & .1569 \\
\hline
\end{tabular}

Notes: Table reports the mean of after-tax share of premiums borne by federal employees over time. First column shows means for postal workers, and second for non-postal workers. 


\begin{tabular}{|c|c|c|c|}
\hline Variable & Overall & Postal Sample & $\begin{array}{l}\text { Non-Postal } \\
\text { Sample }\end{array}$ \\
\hline ATSHARE & .15 & .065 & .235 \\
\hline Family Takeup Rate & .615 & .688 & .542 \\
\hline Single Takeup Rate & .253 & .221 & .286 \\
\hline $\begin{array}{l}\text { Government Share of Family } \\
\text { Premiums }(\$ 2002)\end{array}$ & 4835 & 5415 & 4256 \\
\hline $\begin{array}{l}\text { Employee Share of Family } \\
\text { Premiums (\$2002) }\end{array}$ & 1064 & 557 & 1571 \\
\hline $\begin{array}{l}\text { Total Family Premiums } \\
\qquad(\$ 2002)\end{array}$ & 5899 & 5972 & 5826 \\
\hline $\begin{array}{l}\text { Government Share of Single } \\
\text { Premiums (\$2002) }\end{array}$ & 2174 & 2432 & 1915 \\
\hline $\begin{array}{l}\text { Employee Share of Single } \\
\text { Premiums (\$2002) }\end{array}$ & 468 & 246 & 691 \\
\hline $\begin{array}{l}\text { Total Single Premiums } \\
\qquad \$ 2002)\end{array}$ & 2642 & 2678 & 2606 \\
\hline Real Wage (\$2002)/10000 & 4.57 & 4.23 & 4.91 \\
\hline Nonwhite & .238 & .256 & .219 \\
\hline Veteran & .263 & .298 & .227 \\
\hline Handicapped & .071 & .074 & .067 \\
\hline Number of Observations & 24480 & 12440 & 12440 \\
\hline
\end{tabular}

Notes: Table shows sample means from the data set described in text. First column shows full sample means; second column shows means for postal sample only; third column shows means for non-postal sample only. 


\begin{tabular}{|c|c|c|}
\hline \multicolumn{3}{|c|}{ Table 3: Takeup Results } \\
\hline Variable & Family Takeup & Single Takeup \\
\hline ATSHARE & $\begin{array}{c}-0.068 \\
(0.016) \\
{[-0.022]}\end{array}$ & $\begin{array}{c}0.036 \\
(0.012) \\
{[0.028]}\end{array}$ \\
\hline Real Wage (\$2002) & $\begin{array}{c}.035 \\
(.001)\end{array}$ & $\begin{array}{l}-.008 \\
(.001)\end{array}$ \\
\hline Age Less than 25 & $\begin{array}{c}.242 \\
(.030)\end{array}$ & $\begin{array}{c}.044 \\
(.023)\end{array}$ \\
\hline Age 25-29 & $\begin{array}{c}.383 \\
(.030)\end{array}$ & $\begin{array}{l}-.006 \\
(.023)\end{array}$ \\
\hline Age $30-34$ & $\begin{array}{c}.267 \\
(.029)\end{array}$ & $\begin{array}{l}-.081 \\
(.022)\end{array}$ \\
\hline Age 35-39 & $\begin{array}{c}.258 \\
(.030)\end{array}$ & $\begin{array}{l}-.193 \\
(.022)\end{array}$ \\
\hline Age $40-44$ & $\begin{array}{c}.371 \\
(.028)\end{array}$ & $\begin{array}{l}-.148 \\
(.021)\end{array}$ \\
\hline Age 45-49 & $\begin{array}{c}.390 \\
(.029)\end{array}$ & $\begin{array}{l}-.187 \\
(.022)\end{array}$ \\
\hline Age $50-54$ & $\begin{array}{c}.308 \\
(.027)\end{array}$ & $\begin{array}{c}-.094 \\
(.021)\end{array}$ \\
\hline Age 55-59 & $\begin{array}{c}.471 \\
(.041)\end{array}$ & $\begin{array}{l}-.294 \\
(.031)\end{array}$ \\
\hline Nonwhite & $\begin{array}{c}.095 \\
(.004)\end{array}$ & $\begin{array}{c}-.104 \\
(.002)\end{array}$ \\
\hline Veteran & $\begin{array}{c}.051 \\
(.004)\end{array}$ & $\begin{array}{l}-.070 \\
(.003)\end{array}$ \\
\hline Veteran Status Missing & $\begin{array}{c}.025 \\
(.002)\end{array}$ & $\begin{array}{l}-.049 \\
(.003)\end{array}$ \\
\hline Handicapped & $\begin{array}{l}-.203 \\
(.011)\end{array}$ & $\begin{array}{l}-.038 \\
(.002)\end{array}$ \\
\hline Handicap Status Missing & $\begin{array}{c}.056 \\
(.020)\end{array}$ & $\begin{array}{c}.225 \\
(.008)\end{array}$ \\
\hline Number of Observations & 24480 & 24480 \\
\hline
\end{tabular}

Notes: Estimates of equation (1) in text. Standard errors in parentheses; elasticity in first row in square brackets. Regressions also control for fixed effects for state, year, postal/non-postal, and sex/income group. First column shows regression results for family takeup, second for single takeup. 


\begin{tabular}{|c|c|c|c|c|c|c|}
\hline \multicolumn{7}{|c|}{ Table 4: Health Benefits Costs Results } \\
\hline \multirow[t]{2}{*}{ Variable } & \multicolumn{3}{|c|}{ Family } & \multicolumn{3}{|c|}{ Self } \\
\hline & Worker & Gov’t & Total & Worker & Gov't & Total \\
\hline ATSHARE & $\begin{array}{c}-150 \\
(31.9)\end{array}$ & $\begin{array}{c}-312 \\
(13.6)\end{array}$ & $\begin{array}{c}-462 \\
(40.4)\end{array}$ & $\begin{array}{l}-70.7 \\
(11.6)\end{array}$ & $\begin{array}{c}-107 \\
(11.6)\end{array}$ & $\begin{array}{c}-178 \\
(19.3)\end{array}$ \\
\hline $\begin{array}{l}\text { Real Wage } \\
(\$ 2002)\end{array}$ & $\begin{array}{c}1.98 \\
(.893)\end{array}$ & $\begin{array}{c}9.12 \\
(.379)\end{array}$ & $\begin{array}{c}11.1 \\
(1.13)\end{array}$ & $\begin{array}{c}1.97 \\
(.325)\end{array}$ & $\begin{array}{c}10.3 \\
(.326)\end{array}$ & $\begin{array}{c}12.3 \\
(.540)\end{array}$ \\
\hline $\begin{array}{l}\text { Age Less } \\
\text { than } 25\end{array}$ & $\begin{array}{c}-325 \\
(58.0)\end{array}$ & $\begin{array}{l}-86.0 \\
(24.6)\end{array}$ & $\begin{array}{c}-411 \\
(73.4)\end{array}$ & $\begin{array}{l}-255 \\
(21.1)\end{array}$ & $\begin{array}{l}-142 \\
(21.2)\end{array}$ & $\begin{array}{c}-396 \\
(35.1)\end{array}$ \\
\hline Age $25-29$ & $\begin{array}{c}-151 \\
(58.8)\end{array}$ & $\begin{array}{l}-70.1 \\
(25.0)\end{array}$ & $\begin{array}{c}-221 \\
(74.3)\end{array}$ & $\begin{array}{l}-392 \\
(21.4)\end{array}$ & $\begin{array}{l}-184 \\
(21.4)\end{array}$ & $\begin{array}{c}-575 \\
(35.5)\end{array}$ \\
\hline Age $30-34$ & $\begin{array}{c}-307 \\
(56.3)\end{array}$ & $\begin{array}{l}-99.3 \\
(23.9)\end{array}$ & $\begin{array}{c}-406 \\
(71.1)\end{array}$ & $\begin{array}{l}-290 \\
(20.5)\end{array}$ & $\begin{array}{l}-156 \\
(20.5)\end{array}$ & $\begin{array}{c}-445 \\
(34.0)\end{array}$ \\
\hline Age $35-39$ & $\begin{array}{c}-535 \\
(57.0)\end{array}$ & $\begin{array}{l}-209 \\
(24.2)\end{array}$ & $\begin{array}{c}-744 \\
(72.0)\end{array}$ & $\begin{array}{l}-307 \\
(20.7)\end{array}$ & $\begin{array}{l}-187 \\
(20.8)\end{array}$ & $\begin{array}{c}-494 \\
(34.4)\end{array}$ \\
\hline Age $40-44$ & $\begin{array}{c}-472 \\
(55.3)\end{array}$ & $\begin{array}{c}-218 \\
(23.5)\end{array}$ & $\begin{array}{c}-689 \\
(69.9)\end{array}$ & $\begin{array}{l}-320 \\
(20.1)\end{array}$ & $\begin{array}{l}-210 \\
(20.1)\end{array}$ & $\begin{array}{c}-530 \\
(33.4)\end{array}$ \\
\hline Age $45-49$ & $\begin{array}{c}-314 \\
(55.9)\end{array}$ & $\begin{array}{l}-99.8 \\
(23.7)\end{array}$ & $\begin{array}{c}-414 \\
(70.6)\end{array}$ & $\begin{array}{l}-281 \\
(20.3)\end{array}$ & $\begin{array}{l}-129 \\
(20.4)\end{array}$ & $\begin{array}{c}-410 \\
(33.8)\end{array}$ \\
\hline Age $50-54$ & $\begin{array}{c}-554 \\
(53.2)\end{array}$ & $\begin{array}{l}-184 \\
(22.6)\end{array}$ & $\begin{array}{c}-738 \\
(67.2)\end{array}$ & $\begin{array}{c}-327 \\
(19.3)\end{array}$ & $\begin{array}{c}-192 \\
(19.4)\end{array}$ & $\begin{array}{c}-519 \\
(32.1)\end{array}$ \\
\hline Age $55-59$ & $\begin{array}{c}-389 \\
(79.4)\end{array}$ & $\begin{array}{l}-104 \\
(33.7)\end{array}$ & $\begin{array}{l}-493 \\
(100)\end{array}$ & $\begin{array}{l}-276 \\
(28.9)\end{array}$ & $\begin{array}{l}-131 \\
(28.9)\end{array}$ & $\begin{array}{c}-407 \\
(47.9)\end{array}$ \\
\hline Nonwhite & $\begin{array}{c}53.9 \\
(7.02)\end{array}$ & $\begin{array}{c}24.9 \\
(2.98)\end{array}$ & $\begin{array}{c}78.8 \\
(8.87)\end{array}$ & $\begin{array}{l}-20.8 \\
(2.55)\end{array}$ & $\begin{array}{l}-39.7 \\
(2.56)\end{array}$ & $\begin{array}{l}-60.5 \\
(4.24)\end{array}$ \\
\hline Veteran & $\begin{array}{c}19.3 \\
(7.00)\end{array}$ & $\begin{array}{c}13.4 \\
(2.95)\end{array}$ & $\begin{array}{c}32.7 \\
(8.79)\end{array}$ & $\begin{array}{c}14.7 \\
(2.53)\end{array}$ & $\begin{array}{l}-10.1 \\
(2.54)\end{array}$ & $\begin{array}{c}4.57 \\
(4.20)\end{array}$ \\
\hline $\begin{array}{l}\text { Veteran } \\
\text { Missing }\end{array}$ & $\begin{array}{c}12.0 \\
(4.84)\end{array}$ & $\begin{array}{l}-3.59 \\
(2.05)\end{array}$ & $\begin{array}{c}8.38 \\
(6.11)\end{array}$ & $\begin{array}{c}1.23 \\
(1.76)\end{array}$ & $\begin{array}{l}-1.15 \\
(1.76)\end{array}$ & $\begin{array}{c}.075 \\
(2.92)\end{array}$ \\
\hline Handicap & $\begin{array}{c}155 \\
(21.9)\end{array}$ & $\begin{array}{l}-82.3 \\
(9.28)\end{array}$ & $\begin{array}{c}72.6 \\
(27.6)\end{array}$ & $\begin{array}{l}-51.2 \\
(7.94)\end{array}$ & $\begin{array}{l}-108 \\
(7.96)\end{array}$ & $\begin{array}{c}-159 \\
(13.2)\end{array}$ \\
\hline $\begin{array}{l}\text { Handicap } \\
\text { Missing }\end{array}$ & $\begin{array}{c}38.0 \\
(38.8)\end{array}$ & $\begin{array}{c}79.1 \\
(16.5)\end{array}$ & $\begin{array}{c}117 \\
(49.0)\end{array}$ & $\begin{array}{c}108 \\
(14.1)\end{array}$ & $\begin{array}{c}127 \\
(14.1)\end{array}$ & $\begin{array}{c}235 \\
(23.4)\end{array}$ \\
\hline Num Obs & 24479 & 24479 & 24479 & 24476 & 24476 & 24476 \\
\hline
\end{tabular}


Notes: Estimates of equation (1) in text. Standard errors in parentheses. Regressions also control for fixed effects for state, year, postal/non-postal, and sex/income group. First three columns shows regression results for family premiums, second three columns for single premiums. Within each set of columns, first column shows effect on worker share of premiums, second column shows effect on government share of premiums, and third column shows effect on total premiums. 
Table 5: Specification with Second-Level Interactions

Dependent Variable

Family Takeup

Single Takeup

Employee Premiums, Family Plans

Government Premiums, Family Plans

Total Premiums, Family Plans

Employee Premiums, Self Plans

Government Premiums, Self Plans

Total Premiums, Self Plans
ATSHARE Coefficient

$-.071$

$(.062)$

$-.038$

$(.051)$

$-189$

$-357$

$-546$

(151)

$-238$

$-159$

$-397$

$(88.7)$

Notes: Estimates of equation (2) in text. Standard errors in parentheses. Each row shows coefficient on ATSHARE from a separate regression, where dependent variable is shown in first column. Regressions also control for fixed effects for state, year, postal/non-postal, and sex/income group; and for interactions of postal/non-postal times sex/income group; postal/nonpostal times state; sex/income times state; postal/non-postal times year; sex/income times year; and state times year. 


\begin{tabular}{|c|c|c|c|c|c|c|}
\hline$\equiv$ & 漓 & $\frac{2}{2}$ & 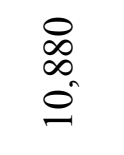 & $\bar{\phi}$ & 然 & 总 \\
\hline$\approx$ & 总 & $\frac{0}{n}$ & है & $\bar{\sigma}$ & 管 & 喜 \\
\hline$\Xi$ & 列 & $\stackrel{2}{n}$ & $\begin{array}{l}\stackrel{\circ}{\mathrm{m}} \\
\stackrel{\mathrm{O}}{=}\end{array}$ & 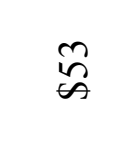 & $\stackrel{\circ}{\circ}$ & 总 \\
\hline$\overline{5} \approx$ & 总 & $\frac{0}{n}$ & $\frac{8}{\tilde{c}}$ & $\stackrel{\infty}{\circ}$ & 鸪 & $\stackrel{\circ}{\bar{\nu}}$ \\
\hline 䇏 & 声 & 喜 & 要 & $\frac{m}{\bar{n}}$ & 楀 & $\vec{b}$ \\
\hline$\stackrel{2}{2}$ & 秓 & 囍 & 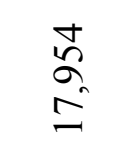 & $\frac{\overline{\bar{n}}}{}$ & 管 & 总 \\
\hline$\frac{1}{3}$ & 声 & 尌 & 示 & F & 管 & 总 \\
\hline 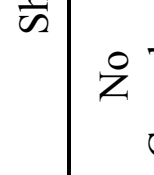 & 释 & 槖 & 壱 & 亭 & 管 & 嘉 \\
\hline
\end{tabular}




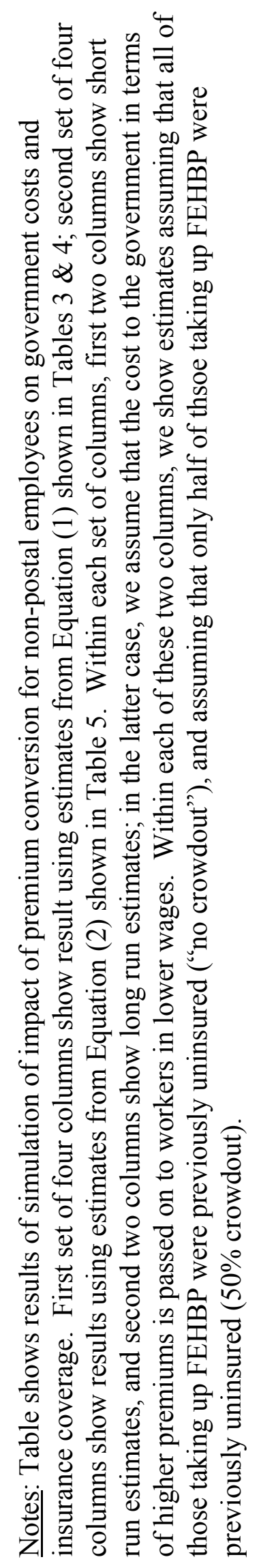


$\exists V \forall H S \perp \forall$ |ełsoduon - jejsod

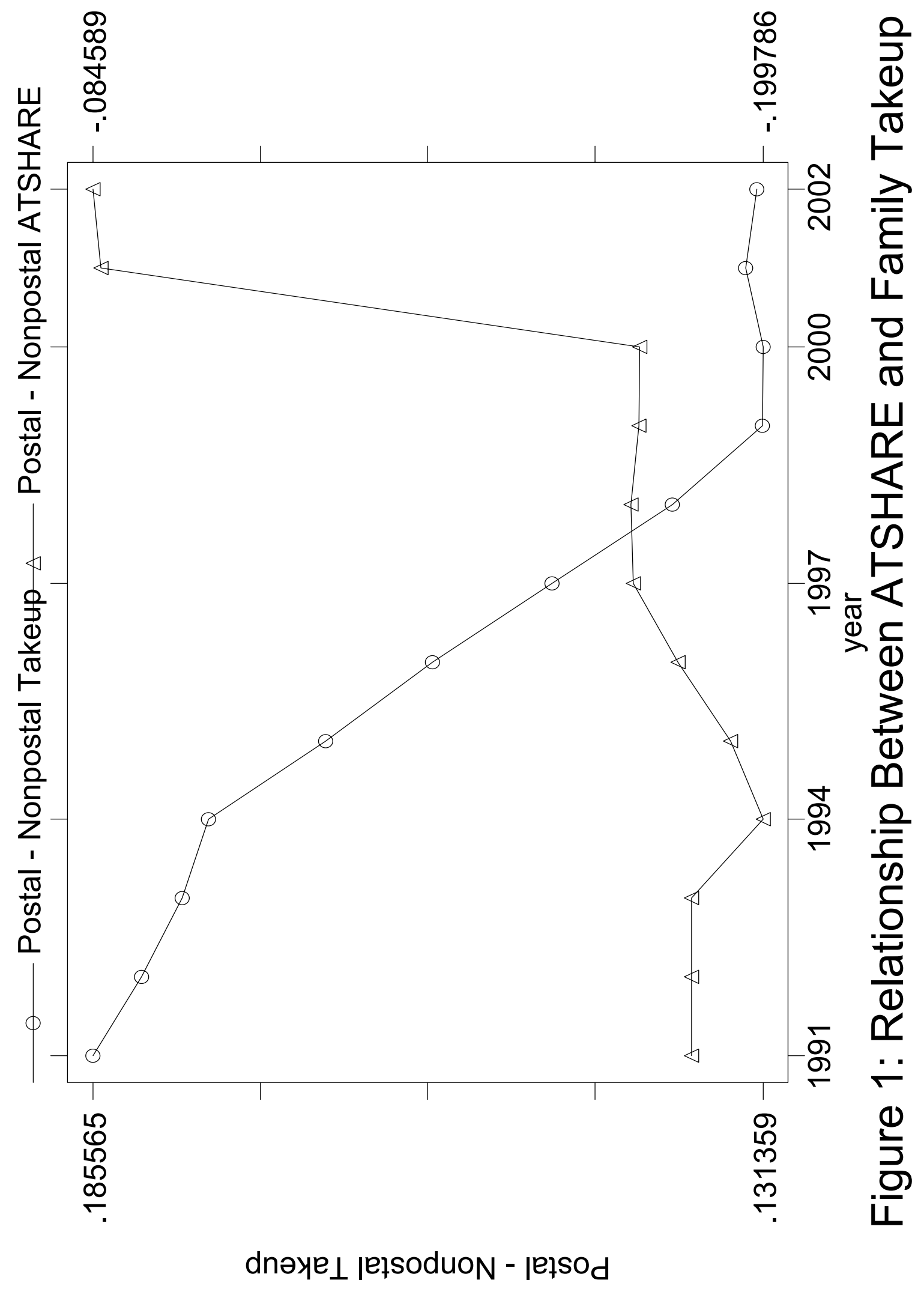

